\title{
Health Knowledge, Awareness \& Social Stigma as Reflected in Egyptian Drama - HIVIAIDS as Paradigm
}

\author{
Jailan Mahmoud Sharaf \\ Faculty of Mass Media \& Communication Technology \\ Suez University, Egypt
}

\begin{abstract}
The purpose of the study to explore the content of drama as folk format to be utilized as educational entertainment spectacle to inform, educate awareness of HIVIAIDS disease and maintain the society from stigmatizing the infected people. The study is considered a qualitative research using content analysis questionnaire to analyze five Egyptian drama storytelling produced to address the HIVIAIDS disease including the plot, characters, knowledge, awareness and social stigma. The results indicate that the information is limited to the transmission of the virus. We found that the infected people are stigmatized by the society although they have to receive their rights as human beings.
\end{abstract}

Keywords: Drama content analysis, HIVIAIDS, knowledge, Awareness, Social stigma.

\section{Introduction}

Media may not only tell us what to think, but may also tell us how and what to think about. McCombs \& Estrada,1997 argued that the implication is that when the media focus on certain issues they can actually convince people into thinking that those issues are important, as audience agenda priorities are influenced by the agenda priorities of the media (Kawmena.2005) ${ }^{(1)}$.

Today's media have a daily life task of promoting science, as a prominent role in contemporary life. Drama storytelling can be used by science communication practitioners to fulfill various goals starting from transmitting information or reshaping science stories to raise consciousness about science as well as inspiring people to take interest in science \& accordingly its societal implications.

Francis et al argued that drama as folk format can be used in HIV awareness. Drama can be utilized as educational entertainment spectacle the audience acquire cognitive the prevention of HIV (Francis DA et al. 2011,15-28)(2).

Drama can be used as a format to engage with audience through drama structure, content, actors, relationships, \& reframe evidence of epidemic disease syndrome as HIVIAIDS.

People who are infected by HIVIAIDS are discriminated by others and evicted from their homes as they are stigmatized from the society. It is always known that heterosexual is the main process for the infection of HIV that many societies don't allow to discuss openly. (Norman LR, .2003) ${ }^{(3)}$. In this study we will try to explore that the treatment of the content of drama to HIVIAIDS is concerned as a tool to inform, educate awareness and maintain the society from stigmatizing the infected people.

\section{Statement of The Problem}

Due to the scientific literacy, this study is tackled to explore that the Egyptian drama as a communication cultural format has maintained the cultural boundaries of science to increase health knowledge, awareness and social stigma towards HIV \& AIDS. The study is dealing with the content treatment to health issues which are depicted through drama storytelling, to address how drama presents the social reality of health issues related to HIVIAIDS.

\section{Significance of the Study}

- Through drama storytelling we can contribute to provide information about HIVIAIDS as well as awareness how to avoid acquiring it.

- It is crucial to inform viewers - who may include, politicians, policy makers and grassroots organizations that people with HIVIAIDS are being treated unfairly.

- Drama storytelling is an alternative for the infected people to display and understand the challenges they are facing, as it is difficult to find someone infected can testimony on camera and reveal his/ her identity.

- To protect the infected people from social stigma.

\section{Objectives of the Study}

- To address that the Egyptian film is concerned to display HIVIAIDS as mild or severe disease.

- To recognize that the main theme of the Films produced is concerned with HIVIAIDS.

- To manifest the type of production of the films is referred to private or governmental sector.

- To show that the film storytelling appointed the social stigma that infected people faces.

- To prove if film storytelling participate in Health Education.

- To clarify that the film storytelling content is concerned with public awareness about HIV prevention, treatment and support relevant policies.

\section{Research Questions}

- What is the main purpose of producing the film?

- How the film portrays the infected with HIVIAIDS?

- Have the film presents health knowledge \& awareness toward HIVIAIDS disease? 
- Have the infected individual of HIVIAIDS experience with multidimensional stigma (social stigma, self stigma, and health professional?

- Have the film show that the infected with HIVIAIDS experience rejection (self isolation, family \& relative rejection, and friends \& community rejection)?

- Have the infected with HIVIAIDS experience discrimination and insult in receiving services (discrimination in receiving services, insult \& humiliation by health professionals, ignorance in giving services)?

\section{Literature Review}

\section{I - Storytelling of Science Journalism in Drama (films)}

The potential for storytelling in science journalism is to focus to present science skills, knowledge, awareness towards health issues. Drama (films) can be used as an approach to science knowledge (Cutting \& Kelly, 2015). ${ }^{(4)}$

The storytelling of drama (films) can explain a complex scientific concept. Earlier studies have reported on the effects of using storytelling in science education. (Walan \& Enochsson, .2019,99). ${ }^{(5)}$ People are naturally storytellers and drama narrative is the preferred way humans gain complex knowledge as well as it is preferable method to share culture (Mclain.2014). ${ }^{(6)}$

Stories help us make sense of our lives. Many traditional stories have been passed down from generation to generation. Storytelling through drama can explain some of the rules and values of the society. In addition, it can be entertaining, exciting and stimulating, where it stimulates thinking about new ideas, explore feelings and think of the theme through the context that is detached from reality ${ }^{(7)}$

Scholars have begun to recognize cinema's role in the public communication of science \& technology as well as its importance in the public understanding of science.

Science communication in popular films revolve around four basic research questions: how is science representation constructed in the production of cinematic texts? (production); how much science, and what kind of science appears in popular films?(content analysis) which is our main concern in this study; what are the cultural interpretation of science \& technology in popular films? (cultural meanings); What effect, if any, does the fictional portrayal of science have on science literacy and public attitudes towards science (A. Kirby..2008, 41-42). ${ }^{(8)}$

Researchers who have investigated the public understanding of science have argued that fictional cinema and television have proven to be particularly effective at blurring the distinction between fact and fiction in an increasing visual society. (Barnett,2t al.2006,179) (9)

We are living in what can be described as "Golden Age" for science in movies and on television. Many of the most financially successful films of all time have science at their core and were made in the last decade including CSI (2000) House (2005-2012): the increased popularity of science in entertainment media coincided with the rise of "geek culture" (Kirby..2014)(10)

Science in entertainment media can significantly provide the public with knowledge, especially regarding health issues. Entertainment education involves the intentional use of fiction to raise awareness of social issues.

Movies were frequently used by public health advocates in attempts to present alter behaviours regarding matters of health. (Buccli \& Trench. 2008) ${ }^{(11)}$

Audiovisual materials play a fundamental role in the context of education, care and clinical treatment, as content seem to deal highly with health awareness (Reigada et al..2019). ${ }^{(12)}$

Films related to themes of disease and contagion often fall under the category fantasy, science fiction, or horror.

While with HIVIAIDS topic, films traditionally deal sensitively or realistically.

Scholarly literature has focused on the inadequacy of capturing the correct science behind disease transmission, spread, and illness, or anachronistic characters in films concerning historical epidemics. (Han \& R. Cuurtis..2020). (13)

\section{II- HIVIAIDS \& Social, Cultural Dynamics}

AIDS is a shocking and deadly disease that affects people worldwide and, like all infections, it comes without warning. Specifically, childbearing women with AIDS face constant psychological difficulties during their pregnancy period, even though the pregnancy itself may be normal and healthy. (Kontomanolis, et al. 2017,111-118) (14).

HIV infection is not socially tenable in most countries and women living with HIVIAIDS are categorized as harlotry (Ndinda Cet al. 2007,92-101). ${ }^{(15)}$ Very frequently, once women are infected, they may be rejected even by their own families ( $\mathrm{N}$ Kontomanolis et al.2017) ${ }^{(16)}$. Stigma and discrimination among patients with HIVIAIDS cause various problems for the patients and their health systems. (Saki, et al.. 2015) ${ }^{(17) .}$

Numerous social issues emerged related to the role of society on devastating HIV-AIDS since the appearance of the syndrome has reflected an undercurrent of reluctance and rage. (N Kontomanolis, et al. 2017) (18)

Referring to the study conducted by Flavio F. Marsiglia et al .2013, ${ }^{(19)}$ where they utilized a pre and post-test applied on sample of 190 students from large public university in the Southwest United States, by using comparison-group design. study explored that the undergraduate course - called HIVIAIDS: Science, Behavior, and Society - positively affected students' HIV-related knowledge, attitudes, and behavior, although such effects were not explicitly part of the course objectives. The infected people are stigmatized and pushed out of the community (Gaudine A, et al.2010, 38-48) ${ }^{(20)}$.

Stigma is created within the society and attached to cultural, social, spatial \& historical factors (Zhang $\mathrm{L}$, et al. 2012,163-8) ${ }^{(21)}$. The presence of stigma 
and discrimination inevitably leads to significant physical, psychological, and economical side effects (Cooperman NA.2005, 149-156) ${ }^{(22) .}$

$\mathrm{N}$ Kontomanolis et al, 2017, had focused mainly on the potential and catalytic role of stigma, the darkest facet of AIDS, and examines the major effects on childbearing subjects and the role society must play in order to eliminate HIV discrimination ${ }^{(23)}$.

The purpose of Mandana Saki et al. 2015, (24) study was to explain the perceived experiences of the patients from stigma and discrimination and their roles on health-seeking services among patients. This was a qualitative research using content analysis approach and semi-structured interviews, conducted on patients living with HIVIADS, during 2013 - 2014 in Iran. Sampling started purposefully and continued in a snowball. The results showed that the experiences of patients with HIVIAIDS from stigma and discrimination led to exploring three main themes which were multidimensional stigma, rejection, and insult and discrimination in receiving health services.

Health-related stigma is a social process which appears as isolation, rejection, blame or devaluation (Weiss MG et al.. 2006 ) (25) . Stigma and discrimination are world events which seriously affect the lives of people with HIV prevention (Brooks RA, et al. 2005, 737-44) ${ }^{(26)}$.

\section{II - HIVIAIDS in Drama Storytelling}

Drama Storytelling can be used as an entertainment-education format to increase health knowledge and to promote visits to health clinic.

HIVIAIDS is among health issues addressed in the drama aired worldwide (P. Do , \& Kinacid, 2006, 301-25) ${ }^{(27)}$.

In spite HIVIAIDs emerged 1981, we found that the Independent filmmakers - The non-Hollywood dramatize the crisis. "Vito Russo" the author of "The Celluloid Closet" book about HIV had died of AIDS before seeing his book as a film on 1995.

Many have criticized the media's reluctance to tackle HIVIAIDS, including the film "Industry" (Singal, \& Rogers..2005, 3-15) ${ }^{(28)}$. Even "Rock Hudson" - one of Hollywood's owner - who died of AIDS in 1985, the major studios didn't produce any film regarding that damned disease. Until "Phildelphia" Film became a box office hit on 1993, as well as "Tom Hanks" \& "Bruce Springster" won Oscar.

(Goldman.1987, 557-561) ${ }^{(29)}$ indicated that the uses of films to provide knowledge about AIDS can decrease frustration \& be sympathy with the infected individual. Also, Sawyer (1991) ${ }^{(30)}$ argued that viewing films regarding AIDS can support people to recognize the disease and be influenced.

However, Jae Eun Chung. 2014, ${ }^{(31)}$ study trying to link between watching of TV dramas \& viewers' perception about health, healthcare \& health knowledge. The study findings indicated that heavy viewing of medical drama was related to greater health knowledge but more among the more educated than among the less educated.
Aitkan \& Dey.1998, ${ }^{(32)}$ had analyzed the following films: "Zero Patience", "Jeffrey", "And The Band Played On" and "Philadelphia" , they concluded that most films about AIDS are about dying, they fail to deal with the idea of living with HIVIAIDS. Feature films often portray homosexuality in the ways that are campy or tragic, perhaps filmmakers believe that they must use "tear jerkers" to receive a positive response from the audience.

In 2007, HBO released "Life Support" film, where it portrays the daily experience and struggles of black woman living with HIVIAIDS. The film focuses that many HIV patients are already at a socioeconomic disadvantages that affects proper healthcare (Moore, et al..2014,110-118) (33).

Besides, (Mtry,2017), (34) asserted that drama stigmatize in portraying the ill individuals.

Due to Kaiser Family Foundation (1997) ${ }^{(35)}$ they assumed that through TV medical drama, technical language are simplified for viewers understanding, dramatic plot are vivid, easy to follow, which can help with knowledge gains \& retention. Especially that TV drama are often heavily consumed by the people in lower socioeconomic status.

Referring to (Farrell \& Goodnight .1981, 271-330) (36) argued that the film illustrates the problems of communicative competence between specialists and publics. (Kirby.2003,54-60) (37) suggested that films operate as virtual witnessing, where the images and narratives influence how individual understands, accepts, or rejects scientific knowledge.

\section{Methodology, Results \& Discussion}

\section{Methodology}

The present study is a qualitative research using conventional content analysis. Qualitative conventional content analysis is a method that can clarify the concealed patterns from the inside of data content. This study sought to analyze the content of (5) Egyptian drama storytelling that were produced to address the HIVIAIDS disease, the portray or delineation of the characters, the plot as well as how each film deals with knowledge, awareness \& social stigma and finally social \& cultural dynamics of HIV. The films are as follows:

1. Film "Soldier Midnight", 1991.

2. Film "Love In Taba", 1992.

3. Film "Disco Disco", 1993.

4. Film "Red Agenda", 2000.

5. Film "Assmaa" ( The Names), 2011.

\section{Research Categories:}

At the heart of any content analysis is the category system used to classify media content. The major categories of this study are the characteristics of the film, character categories, and the plot of the film category. Each major category includes appropriate subcategories as discussed below. 
- The unit analysis is "The Film"

- Tool of gathering data: Designing a content analysis questionnaire determined with exhaustive and exclusive categories.

- The unit and categories analysis are as follows:

- The unit analysis: The Film

- Measurement unit: the theme in film

- Time unit: minutes as it is the unit to count time of the film duration.

\section{The Format categories consist of:}

- The characteristics of the film include the film name, date of production, Type of Production Company (public/private sector).

- The Genre of the film (Romance, tragedy, melodrama, action, comedy)

\section{The Character Categories:}

- The type of character include: main, pivotal, secondary, marginal, incidental and other.

- The physical dimension (gender, age, outlook)

- The Sociological dimension (Sector/level/ category, Profession).

- Education (illiterate, reads \& writes, diploma, University, not clear

- Standard of Living.

- Psychological dimension (Ethical standards, Personal objectives, Psychological problems, the image of the portrayed infected character with HIVI AIDS in the film).

\section{1 - The Content Categories:}

\section{The Plot:}

- The type of the issue.

- The method of film treatment (presenting the issue, presenting the reasons of the issue, presenting the aspects of the issue analyzing the reasons of the issue, presenting results, display solutions, open end, other)

- The time of treatment of the phenomenon.

- The mainstream of treatment to the issue is : knowledge, or awareness, or social stigma (Multidimensional :social stigma, self stigma, health professionals, Rejection: self isolation,family \& relative rejection, Friends \& Community rejection-Discrimination \& Insult in Receiving Service: discrimination \& receiving services, insult $\&$ humiliation by health professionals, ignorance of giving services)

- The denouement of the film ( the final determination of the character)

\section{2 - Coding Reliability:}

To establish a strong, reliable coding, two coders who were trained in the use of the category scheme and coded the viewed material that has been given in this study that fall in the above mentioned categories.

\section{Validity:}

For the validity purpose,. The researcher found that the previously mentioned categories matched the specific research questions that were considered in this study. These categories were measured according to the research questions.

\section{Results}

\section{Characteristics of the Film Study Sample}

The theme of the films study sample is concerned with HIVIAIDS. The films were produced in different years, three were produced in the early nineties (Film "Midnight Soldier, 1991, Film "Love in Taba", 1992, Film "Disco Disco",1993), one at the millennium Film "Red Agenda",2000, and the last Film "Assmaa" (The Names), 2011. The length of the film is between 82 $\min$ to $112 \mathrm{~min}$. All the films are produced by private production companies. This indicate the absence of the government to the importance of the issue to provide health knowledge to the public as drama storytelling is the best medium to reach all the audience with different socioeconomic categories.

\section{Content Categories (The Plot)}

The results show that the films study sample are dealing with HIVIAIDS disease, except Film "Disco Disco" is concerned with the teenage problems including the infection of HIVIAIDS. Film "Soldier Midnight" exposed to social stigma within the plot of the film. Also, film "Assmaa" (The Names) focused on social stigma towards the infected people. The conflict in all the films is dynamic except in film "Red Agenda". Film "Soldier Midnight" the only film that showed that HIVIAIDS had been transmitted through contaminated syringe. Film "Assmaa" (The Names) the heroine sacrifice and carries the virus to fulfill the dream of her infected husband before he dies to bring for him a baby.

Although most films in the nineties covered stories about AIDS, most of them indicated that transmission of infection is carried out through sexual relations only, but Film "Soldier Midnight", 1991, revolved around the injury of a youth HIVIAIDS due to blood transmission by contaminated syringe. The infected is the son of soldier (pivotal character/middle class) inspite he is ambitious sportive and wants to be an officer, but he is drawn to be drug addicted. The soldier works efficiently within a successful team to arrest merchants and distributors of drugs. The soldier tries to treat his son from drug addiction, but he is not responding. Rather, his is exposed to car accident and at the hospital he is infected with AIDS through blood transmission using contaminated syringes. Accordingly the young man's dreams are lost, so his father decides to end his son's life by killing him due to social stigma. The film is considered Melodrama Thriller.

While, "Love In Taba", 1992, a tragedy light film that portrayed three young friends of high class and they are considered to be the main characters Mustafa (Mamdouh AbElalim- actor), Fakhry (Hisham AbdelHamid-actor) and Khaled (Wael Nour-actor). They traveled to Sharm El Sheikh, where they meet three tourists, and have an illegal relationship with them. Later, they discovered that the tourists are infected with AIDS, so the three collapsed. Each one tries to escape from his family, and events escalate. 
Also,"Red Agenda", 2000, tragedy light film where a dermatologist (main character) is surprised by his cousin (secondary character/middle age/high class) complains about a sudden illness, and by signing a medical examination. It becomes clear that he has a rapid spread of syphilis. He detects that his cousin has been infected with HIVIAIDS a disease that is transmitted through sexual relations, and from here the doctor begins tracking the threads of his cousin's multiple relationships. The doctor realizes the danger of the disease to society because of its rapid spread, and begins the journey of searching the source of the diffusing of the virus with no vain as shown at the end of the film.

However, "Disco Disco", 1993, a tragedy thriller film where the events is taking place in Maadi - a famous place in Cairo - the plot of the film is around a mixed secondary school with some models of students of varying characters and morals according to their home environment as well as their parents status. The parents use to meet at the club where there is contact relationship. The film is tackling different issues that facing teenagers as taking drugs, negligence of parents to their children, the extremist Islamism, poverty, illegal relationships and AIDS infection where the infected is an incidental male character is classified from low socioeconomic category. The film raised the issues that faces the teenage more than exploring a solution to the problems

Film "Assmaa" (The Names) tragedy thriller, 2011,"Assmaa" (Hind Sabry-actress ) lives with her father "Hosny" (Sayed Ragab) in one of the hamlets. She makes handmade carpets and sells them in the market, until she meets "Musaad" (Hany Adel-actor) the recruiter. He cultivates his land with his brother "Yassin" (Muhammad Yunus-actor) who is sterile. "Mussad" wants to have a son to inherit the land. "Assmaa" refuses to stop selling carpets in the market, until one of the competitors assaults her. "Mussad" quarrels with that guy and kills him by mistake. She feels that he is imprisoned because of her. When his brother "Yassin" hears about "Mussad" infection with HIVIAIDS, he thinks that "Assmaa" is the one who transmits the infection to him with her misconduct. "Asmaa" insists to be pregnant from her husband to give birth to him as a sacrifice. "Mussaad" dies before she gives birth. "Yassin" gives "Assma" two options, one to give them the baby if he is a boy, and in case the baby is girl to take her and leave. "Assmaa" lives in the city with her father "Hosny" and her daughter "Habiba" who is not infected with the virus as "Assmaa" is only carrier of the virus. "Assmaa" works in the airport as a cleaner, without providing her health certificate, so when they know of her illness, they dismiss her. She joins an Association for AIDS patients under the leadership of "Dr. Hady" (Boutros Ghaly-actor), "Assmaa" suffers from gallbladder disease and all hospitals refuse to receive her, as well as all surgeons refuse to perform the operation because of AIDS. One of the good people offers to make for her the surgery in his hospital in return for telling him how she is infected, but she refuses. The presenter of the "On Hot Tin" program, "Mohsen Al-Sisi" (Majed Kadwani-actor) takes the opportunity to show "Assmaa" in the program and expose the harsh community. She refuses to show her face in the show due to stigma and discrimination against the infected individuals. At the end of the program "Assmaa" decides to disclose her character, finally the presenter announces that an anonymous donates 300,000 Egyptian pounds to "Assmaa". The presenter is the donator as he donates with the installment of his villa in Marasi - North coast of Egypt. We observe that films focus the point of the stigma of the virus without presenting solution to the problem.

\section{Delineation of the infected characters}

The results indicated that the infected characters in Film "Assmaa" (The Names) and Film "Love in Taba" are main characters, while in Film "Red Agenda" \& Film "Midnight Soldier" the characters are pivotal, but in Film "Disco Disco" the character is incidental.

The films sample of study exposed to infected characters with HIVIAIDS from different socioeconomic categories, as shown in Film "Assmaa" (The Names) \& Film "Disco Disco" the characters are related to low socioeconomic category, while in Film "Soldier Midnight" from middle class category, although the characters in Film "Love in Taba" \& Film "Red Agenda" are related to high class category. This shows that the virus can be diffused at any social category."Assmaa" (The Names) is the only character shown to be fighter. She is fighter to live with HIVIAIDS, optimistic, sacrifice as well as she is representing female gender.

\section{Discussion}

From the content analysis of the films study sample we conclude that the health problem HIVIAIDS is the central of the plot of drama storytelling and intertwined in the relationships among the characters. Regarding the knowledge, awareness \& the stigma as well as discrimination that faces the infected characters we find the following results which reflects the purpose of the study, the objective \& research questions:

\section{The Knowledge \& Awareness}

Due to the content analysis of the films sample study, we find that the diffusion of the virus happens through sexual relationships especially the illegal ones as shown in the following films: "Red Agenda" \& Love in Taba" . In film "Disco Disco" the disease is mentioned entirely within the storytelling of the film.

But in "Assmaa" (The Names) film, it shows that the virus has been transferred to the main character through her husband who has been infected during he was imprisoned. While at film "Soldier Midnight" the disease has been transferred to the infected character by contaminated syringe.

But the films didn't give any information or knowledge about the disease, as its' mergence and avoidance of acquiring the virus. It only shades light on the disease without deep information. Even the films sample study didn't show how to avoid acquiring that virus or how to protect yourself, only just to avoid 
illegal relationships and taking drugs through syringe or contaminated syringe.

\section{Stigma \& Discrimination}

This category has been analyzed and divided into subcategories as follows:

\section{Multidimensional Stigma}

The most characters in the film study sample have painful experiences resulted from being labeled as HIV/AIDS-positive patients, especially the character "Assmaa" as she is forced to leave her hamlet with her father and baby due to the social and cultural dynamics. This category included such subthemes as social stigma, self-stigma and treatment system stigma.

\section{Social Stigma}

"Assmaa" has been labeled by her husband's brother as adultery and is forced to leave the hamlet. In "Soldier Midnight" Soldier Hassan has killed his son once he knows that he has been infected with HIV/ AIDS to avoid stigma. While the other characters in the other films who represent male gender don't expose to stigma or discrimination from the society.

\section{Self-Stigma}

The infected characters in the films sample of study show the feelings of shame and embarrassment because of HIVIAIDS. As in "Assmaa" film she doesn't want anyone to know that she is carrying the virus HIV/ AIDS.

\section{Health Professionals}

Physicians and health professionals labeled positive HIV patients with stigma and discrimination as shown in film "Assmaa" (The Names) evidently as she is suffering gallbladder disease and all hospitals refuse to receive her, as well as all surgeons refuse to perform the operation because of AIDS. This is not addressed at in the other films sample study "Love in Taba" or "Soldier Midnight" or "Red Agenda", except "Disco Disco" as "Metwally" has been arrested due to the discovering of his infection.

\section{Rejection}

The characters in the films sample of study are identified as patients with HIVIAIDS in the community, they face isolation (self-isolation, social isolation and family members \& relatives \& friends rejection). They feel loneliness and hopelessness especially in Film "Assmaa" (The Names) and Film "Love in Taba".

\section{Discrimination and Insult in Receiving Services}

Almost all the characters in the films sample of study encountered challenges while receiving health and medical services. Film "Assmaa" (The Names) shows that most of the patients mentioned in the AIDS community face discriminatory behaviors offered by physicians, health professionals' "discrimination in giving services", unwillingness in giving services to them, lack of cooperation in acceptance of patients with HIV in hospitals, "insult and humiliation by health professionals", and "ignorance in giving services".

\section{Conclusion}

The HIV infection, has led people - especially women - to avoid disclosing their HIV status to anyone even their family, and this globally observed phenomenon. The society has responsibility to identify and eliminate biases, not only in the general population, but also in clinical settings, so that all sick individuals are respected and cared for, regardless of race, religion, gender, nationality, or condition.

According to WHO (2019) , There were approximately 38 million people across the globe with HIVIAIDS and throughout the centuries, women have been mistreated and socially discriminated, living in the shadows, especially in third world countries. This shown in "Assmaa" film, where Assmaa the main character is a change agent for her community due to Rogers arguing the important role of a change agent in getting people to adopt new behaviors or introducing them, as the change agent is influential in ensuring that the adopters can carry out the new behaviors (Rogers,.2003)(38).

Although change agents are usually educators or public health workers. Assmaa is HIV positive, her existence knowledge comes from her experience. The movie shows that the people whom she interacts in the context of the outreach center respect her judgment.

Assmaa film is a form of entertainment education because it creates meaningful dialogue about how the society should associate with behaviors that are sometimes culturally unacceptable. Many social stigmas about HIVIAIDS began before people knew much about the virus. These stigmas develop from misinformation and misunderstanding about the virus. HIV patients needs prevention, to have access to treatment and care, to disclosure, they are seeking support, to interact socially, to announce their identity. The people living with HIVIAIDS-infected individuals should acquire their human rights as they are all influenced by the stigma and discrimination caused by HIVIAIDS. The negative consequences connected to HIV stigma may force the infected people to delay or refuse treatment or hide their disease from others (Saki et al,2015). ${ }^{(39)} \mathrm{A}$ robust national strategic plan was developed to cover the period 2015-2020 with ambitious targets aligned to global targets of $90-90-90$ (90\% of those living with HIV knowing their status, $90 \%$ of those knowing their status are enrolled to treatment and $90 \%$ of those on treatment sustained on treatment to reach viral suppression) set and endorsed globally through the 2016 political declaration for ending AIDS by $2030^{(40)}$. The strategy implementation has faced several challenges. While Egypt's government has pledged national resources to support the procurement of treatment, several gaps in areas of prevention, care, support and the enabling environment persist 
(41). Since the start of the AIDS epidemic, the media has role in shaping the public's perception. Several celebrities as Princess Diana (1991), her son Prince Harry (2016) became spokespeople for HIVIAIDS. The public support, along with their roles in TV and film as an early Frost (1985), The Ryan White Story (1989), Something to Live for:The Alison Gertz Story (1992), Philadelphia (1993) “ER”, (1997), Rent (2005), Holding The Man (2015), Bohemian Rhapsody (2018), which helped audiences gain an empathetic and more examples. Dallas Buyers Club, Philadelphia portray an encounters vivid depiction of the daily struggles and prejudices a HIV positive person have as well as shown in film the Band Played On Kids, often through melodrama fewer films have death with after epidemic diseases (McCrea \& Gotter2019). ${ }^{(42)}$ Finally, we can materialize that there is relationship between science and film as storytelling with visual representations can reflect scientific and technical practices, the dialogue that employ convenient simplified technical language conveys believable understandable conversations among the target audiences and definitely the narrative reflects a drama driven by scientifically credible events. On the other hand, we should draw the attention that medical drama can unconsciously affect viewers' assessment as to which health issue is.

\section{End notes / Bibliography}

${ }^{1}$ Kawmena, Kwansah-Aido. 2005. Topical Issues in Communication and Media Research. New York: Nova Science Publishers. Inc.

${ }^{2}$ Francis DA. Francis D, Khanare F, Beyers C. 2011. Using forum theater to engage youth in sexuality, relationship And HIV education*, Acting on HIV,15-28. Rotterdam:Sense Publishers

${ }^{3}$ Norman LR, Carr R.2003. The Role of HIV knowledge on HIV-Related Behaviours: A Hierarchical Analysis of Adults in Trinidad. Health Edu. Vol;103(3):145-55. doi: 10.1108/09654280310472360

${ }^{4}$ Cutting ,Roger \& Kelly ,Orla. 2015. Creative Teaching in Primary Science. p.99 (Sage).sk.sagepub.com/books/creativeteaching-in-primary-science/i671.xml

${ }^{5}$ Walan. Suzanne \& Enochsson, Ann Brett.2019. The potential of Using a Combination of Storytelling and Drama, When Teaching Young Children Science. European Early Childhood Education Research Journal. Volume 27, Issue 6.

${ }^{6}$ Mclain, Brad.2014. Steps: Where the Drama of Science Meets The Science of Drama. Association of Science \& Technology Centers. Astc.org/past-dimensions-features/stepswhere-the-drama-of-science-meets-the-science-of-drama. Last access on $1 / 05 / 2021$.

${ }^{7}$ Teacher Education through school based Support in India. Storytelling, songs, role play and drama. The Open University. www.TESS-India.edu.in. http:/creative commons.org/licenses. Last access on $1 / 05 / 2021$.

${ }^{8}$ A. Kirby, David.2008. Cinematic Science: The Public Communication of Science \& Technology in Popular Film.. UK.: Routledge. pp41-42

${ }^{9}$ Barnett,Michael. Wagner,Heather. Gtling, Anne. Anderson, Janice. Houle, Meredith \& Kalfka, Alan.2006. The Impact of Science Fiction Film on Student Understanding of Science. Journal of Science Education \& Technology. p179.Vol.15, No.2.

${ }^{10}$ Kirby,David.2014. Science \& Technology in Film:Themes and Representations. Handbook of Public Communicaion of Science \& Technology Academia.edu/35316927/science_and_ Technology_in_Film_themes_and_Representation.
11 Buccli,Massimiano \& Trench ,Brean. 2008. Public Communication of Science \& Technology ,Second Edition. London \& New York: Routledge Taylor \& Francis Group.

12 Reigada,Carla., Martin-Utrila, Salvador., Perez-Ros, Pilar., Anna Sandgsen,Carlos Gomez-Baceiredo, Centeno Beatriz.2019. Understanding Illness/through a Film Festival: An Observational Study.https://doi.org/10.1016/j.heliyon..eo2196.

${ }^{13}$ Han ,Qyuin \& R. Cuurtis,Daniel.2020. Social Responses to Epidemics Depicted by Cinema. (Emergency Infectious Diseases)

14 Kontomanolis,Emmanuel., Michalopoulos, Grigorios., Gkasdaris, Spyridon and Fasoulakis, Zacharias. 2017. The Social Stigma of HIV-AIDS: Society's Role. -Research and Palliative Care.; pp.111-118. Vol.9: doi: 10.2147/HIV. S129992 Retrieved https://www.ncbi.nlm.nih.gov/pmc/articles/ PMC5490433/

${ }^{15}$ Ndinda C, Chimbwete C, McGrath N, Pool R, Mdp G. 2007. Community Attitudes Towards Individuals Living with HIV in Rural KwaZulu-Natal, South Africa. AIDS Care. Vol.19(1): pp.92-101. doi: 10.1080/09540120600888378.

${ }^{16} \mathrm{~N}$ Kontomanolis, Emmanuel. Michalopoulos, Spyridon. Kasdaris, Grigorios and Fasoulakis, Zacharias . (2017). OpCit.

${ }^{17}$ Saki, Mandana., Kermanshahi, Eesa Mohammadi, Sima Mohammad Khan., and Mohraz, Minoo. 2015. Perception of Patients With HIVIAIDS From Stigma and Discrimination. Iran Red Crescent Medical Journal . Vol. 7(6): e23638. doi: 10.5812/ ircmj.23638v2 Retrieved https://www.ncbi.nlm.nih.gov/pmc/ articles/PMC4537784/ last access on 1/05/2021.

$18 \mathrm{~N}$ Kontomanolis, Emmanuel., Michalopoulos, Spyridon, Kasdaris,Grgorios. and Zacharias, Fasoulakis. 2017. OpCit.

${ }^{19}$ F. Marsiglia, Flavio : L. Jacobs, Bertram. Nieri, Tanya .Smith,Scott J., Salamone ,Damien. and Booth,Jaime . 2013. Effects of an Undergraduate HIVIAIDS Course On Students' HIV risk. HSS Public Access. J HIV AIDS Soc Serv. Vol.12(2): pp.172-189.doi:10.1080/15381501.2013.790750. Retrieved from https://www.ncbi.nlm.nih.gov/pmc/articles/PMC3775368/. Last Access on 1/05/2021

${ }^{20}$ Gaudine A, Gien L, Thuan TT, Dung do V.2010. Perspectives of HIV-Related Stigma in a Community in Vietnam: a Qualitative Study. Int J Nurs Stud. 38-48.Vol. 47(1). doi: 10.1016/j.ijnurstu.2009.06.004.

${ }^{21}$ Zhang L, Chow EP, Zhang J, Jing J, Wilson DP. 2012. Describing the Chinese HIV Surveillance System and the Influences of Political Structures and Social stigma. Open AIDS J. Vol. 6:163-8. doi: 10.2174/1874613601206010163.

${ }^{22}$ Cooperman NA, Simoni JM.(2005) Suicidal ideation and attempted suicide among women living with HIVIAIDS. J Behav Med. Vol.28(2): 149-156.

$23 \mathrm{~N}$ Kontomanolis, Emmanuel., Michalopoulos, Spyridon,. .Kasdaris, Grigorios., and Fasoulakis, Zacharias. 2017. OpCit.

${ }^{24}$ Saki, Mandana., Kermanshahi, Eesa Mohammadi, Sima Mohammad Khan., and Mohraz, Minoo. 2015. OpCit.

${ }^{25}$ Weiss ,Mitchell . Ramakrishna, Jayashree, Daryl,Somma 2006. Health-Related Stigma: Rethinking Concepts and Interventions. Psychology Health Med. 277-87 Vol. 11(3): doi:10.1080/13548500600595053. last Access on 1/05/2021

${ }^{26}$ Brooks RA, Etzel MA, Hinojos E, Henry CL, Perez M. 2005. Preventing HIV Among Latino and African American Gay and Bisexual Men in a Context of HIV-Related Stigma, Discrimination, and Homophobia: Perspectives of Providers. AIDS Patient Care and STDs. Vol.19(11): 737-44. doi: 10.1089/apc.2005.19.737. Last Access on 1/05/2021.

${ }^{27}$ P. Do ,Mai \& Kinacid,D Lawrence. 2006. Impact of an Entertainment-Education TV Drama on Health Knowledge \& Behavior in Bangladesh: An Application of Propensity Score Matching. Journal of Health Communication Vol.11(3):301-25 - DOI: 10.1080/10810730600614045 Retrieved from https:// www.researchgate.net/publication/7155284 Impact of an Entertainment-Education_Television_Drama_on_Health_ Knowledge_and_Behavior_in_Bangladesh_An_Application_of_Propensity_Score_Matching 
${ }^{28}$ Singal, A. \& Rogers, E.M.2005. The Role of Popular Narratives in Stimulating the Public Discourse on HIVIAIDS Bollywood's Answer to Hollywood's Phildelphia. South Asian Popular Culture,3, 3-15.

${ }^{29}$ Golden, J.D. 1987. An Elective Seminar to Teach First Year Students the Social \& Medical Aspects of AIDS. Journal of Medical Education,.Vol. 62 (7): 557-561.

${ }^{30}$ Sawyer,R.G.1991. The Effects of Education Videotapes on The Perceived Susceptibility to HIVIAIDS in a Population of a University Freshmen. Dissertation Abstracts Int'l.

${ }^{31}$ Chung ,Jae Eun.2014. Medical Dramas \& Viewers' Perception and Knowledge About Health:Testing Cultivation Effects. Communication Research. https://doi.org/10.1111/ hcre.12026 Retrieved from https://onlinelibrary.wiley.com/doi/ full/10.1111/hcre.12026

${ }^{32}$ Aitken, Joan E.; Dey, Ann M. 1998. Film Portrayal of People with HIVIAIDS. Paper presented at the University of Kansas Annual Film Symposium (Lawrence, KS)

${ }^{33}$ Moore, DaKysha. O. Onsomu, Elijah. A. Abuya, Benta.2014. HIV Prevention Using Films: HIVIAIDS Positive African American Women Respond through interpersonal Relationships in Life Support. Open Journal of Social Sciences, 2, pp.110-118 Published Online November 2014 in SciRes. http://www.scirp. org/journal/jss http://dx.doi.org/10.4236/jss.2014.211016

${ }^{34}$ Mitry ,Caroline.2017. Are We Intensifying the Stigma. A Content Analysis of Movies Portraying Mental \& Psychological Illness in The Egyptian Cinema. Egypt:The American University: School of Global Affairs \& Public Policy.

${ }^{35}$ Kaiser Family Foundation .1997. Survey of ER Viewers. Retrieved from http://KFF.org/womenhealth/1358-ers.cf.

${ }^{36}$ Farrell,T.B. \& Goodnight, G.T.1981. . Accidental Rhetoric: The Root Metaphors of Three Miles Island. Communication Monographs..Vol.48: 271-330.

${ }^{37}$ Kirby,D.A. .2003. Science Advisors, representation and Hollywood films. Molecular Interventions..3(2): 54-60.

${ }^{38}$ Rogers,E.M.2003. Diffusion of Innovation. $5^{\text {th }}$ edition, New York: Free Press.

Saki, Mandana., Kermanshahi, Eesa Mohammadi, Sima Mohammad Khan., and Mohraz, Minoo. 2015. OpCit.

${ }^{40}$ www.egypttoday.com > Article > National-AIDS-ProgramOnly-13K

${ }^{41}$ https://www.unicef.org/egypt/hivaids

42 Megan McCrea \& Ana Gotter.(2019)How the Media Shapes Our Perception of HIVIAIDS. Helathline.com/health/ media-and-perception-of-hiv-aids. 